\title{
Spatio-Temporal Evaluation and Quantification of Pollutant Source Contribution in Little Akaki River, Ethiopia: Conjunctive Application of Factor Analysis and Multivariate Receptor Model
}

\author{
Zelalem Abera Angello",2*, Jens Tränckner², Beshah M. Behailu ${ }^{3}$ \\ ${ }^{1}$ Arba Minch University, AWTI, Arba Minch, Ethiopia \\ ${ }^{2}$ Rostock University, Department of Water Management, Rostock, Germany \\ ${ }^{3}$ Water Development Commission, MoWIE, Addis Ababa, Ethiopia
}

Received: 26 December 2019

Accepted: 16 March 2020

\begin{abstract}
Little Akaki River (LAR) is among the heavily polluted urban rivers in Ethiopia. A bimonthly physico-chemical and heavy metals water quality analysis was conducted aimed at assessing the spatio-temporal characteristics and quantifying sources contributing to the pollution during dry and wet season at 22 montoring stations. Accordingly, laboratory analysis results indicated that most of the constituents deviated from the national and international guideline limits and the river is critically polluted at the middle and downstream segment. Factor Analysis (FA) was used to qualitatively determine the possible sources contributing to the pollution of LAR where three factors are identified that determine the pollution level during wet and dry season explaining $79.26 \%$ and $79.47 \%$ of the total variance respectively. Agricultural and urban runoff (nonpoint pollution sources), industrial and domestic waste are the three dominant factors that contribute to pollution in LAR. On the other hand, pollution sources of heavy metals in LAR are mostly dominated by industrial release whereas urban washouts from garages and automobile oil spills are other possible sources. Cluster Analysis spatially grouped all 22 monitoring stations into four and three clusters during the dry and wet season respectively. USEPA's receptor model, UNMIX, was used to quantify the composition and contribution of LAR constituents. The model predicted quite well with a minimum Signal to Noise ratio $(\mathrm{S} / \mathrm{N})$ of 2.71 and $2.16>2$ and $\mathrm{R}^{2}$ of 0.91 and $0.88>0.8$ for the dry and wet season respectively. The UNMIX model effectively predicted the water quality source composition with a model predicted to measured ratio (P:M) of 1.04 and 1.16 during the dry season and wet season with an average percentage error of $1.38 \%$ and $17.13 \%$ respectively. LAR water quality management approach incorporating all the three pollution sources could be feasible.
\end{abstract}

Keywords: LAR, spatio-temporal assessment, FA, UNMIX, source composition

*e-mail: zelalemabera30@yahoo.com 


\section{Introduction}

Urban rivers of developing countries are often considered as carriers of toxic heavy metals, organic and inorganic nutrients, and are becoming a threat to community [1]. The rivers are serving as a hotspot where pollution from various sources are dumped [2]. Due to the complex and dynamic characteristics of waste released to the rivers, it is becoming extremely difficult to accurately characterize the water quality constituents of these rivers thereby making water quality management more challenging. Hence assessment of spatio-temporal variation of a river water quality is becoming vital in characterizing the different constituents of the river water through routine water quality monitoring programs $[3,4]$.

The spatio-temporal assessment of water quality based on a short duration monitoring campaign will give an erratic result which is difficult to draw a concrete water quality management plan [5]. Nowadays, multivariate statistical techniques (MSTs) such as Factor (FA) and cluster analysis (CA) are becoming a way to effectively evaluate this spatio-temporal variability in a watershed identification of the possible pollution sources [6] where they are applied and found to be successful in evaluating river water quality in South America [5], Asia [6, 7], North America [8], Africa [9, 10], and Europe [11]. Though MSTs, specifically FA, is effective in the qualitative estimation of the type of pollution sources, they have drawbacks in quantifying sources contributing to the pollution of a water environment [12]. Hence, multivariate receptor models (MRMs) have the tendency to fill the gap and they become a tool that can effectively quantify the sources contributing to river pollution. Studies conducted using MRMs such as APCS-MLR [12], UNMIX [13], and PMF [14] have proved effective in estimating the contribution of each source to individual constituents. In Ethiopia, urban river pollution is associated with the high and unplanned expansion of cities, uncontrolled agricultural and urban runoff, and improper domestic and industrial waste release. Moreover, waste generated from different sources in urban areas is released to the rivers without or minimal treatment which makes the rivers a primary pollution hotspot [15]. Due to the lack of continuously monitored water quality data, few studies have been conducted on Little Akaki River (LAR) water quality. The study conducted by Abegaz [16] with two sampling campaigns showed that the distribution of pollutants and heavy metals in LAR deviated from the Ethiopian and international guideline standards. In addition, based on the land use type of the study area, Yilma et.al. [17] classified the LAR in three pollution zones (low, medium, and high). Therefore, it is time to carefully look at the main causes that control the spatial and temporal water quality dynamics in LAR. Hence, the objectives of this study were 1) evaluating the LAR physico-chemical and heavy metal water quality characteristics during dry and wet seasons 2) determination of possible sources contributing to the LAR pollution and classifying the pollutions based on their spatial similarity 3) quantifying the contribution

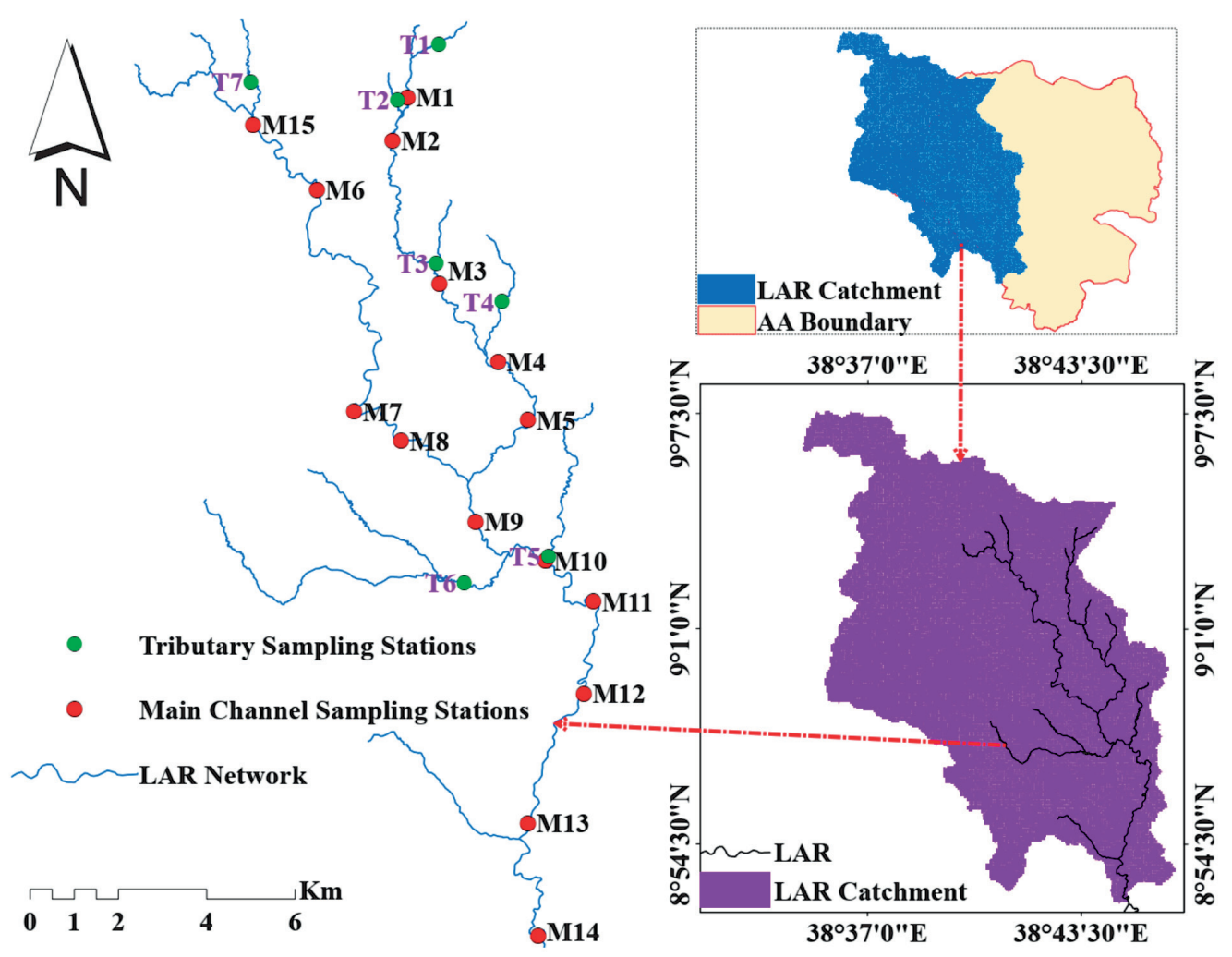

Fig. 1. Study area map and monitoring station locations $(M=$ main channel, $T=$ Tributaries, $A A=$ Addis Ababa $)$ 
and composition of the identified pollution source using USEPA's UNMIX model.

\section{Materials and Methods}

\section{The Study Area}

LAR is located in Addis Ababa, the capital and the largest city of Ethiopia. Geographically, the study area is bounded between $9.06^{\circ} \mathrm{N}$ and $38.69^{\circ} \mathrm{E}$ to $8.89^{\circ} \mathrm{N}$ and $38.75^{\circ} \mathrm{E}$ (Fig. 1). The climate of the area is mostly warm temperate to humid and sub-humid with an altitude ranging from $2200 \mathrm{~m}$ to $2600 \mathrm{~m}$ above sea level. The dry season in the study area ranges from October to May whereas the wet season ranges from June to September. The rainy season in the study area is characterized by rainfall of short duration with an annual depth of $1400 \mathrm{~mm}$. There are three major rivers in the city (Kebena, LAR and Tiliku Akaki River) all originating near the foothills of Entoto. LAR is one of the heavily polluted rivers in the country $[18,19]$ due to the release of industrial, agricultural, and domestic waste into the river with no or minimal treatment. Nearly $52 \%$ of the country's large-scale industries are located in Addis Ababa where most of them discharge their wastewater directly to the river [19]. Moreover, the river is highly impacted by the release of household and agricultural waste. On the other hand, the study conducted by Ghebretekel [20] showed there are a total of six large-scale tanning facilities near LAR only that directly discharge their industrial waste to the river. LAR receives a lot of waste from households, tanneries, shoe factories, detergent and oil industries, abattoir, marble factories, hospitals and schools, soft drink industries and brewery factories. This study generally comprises upstream from the outlet of Gefersa dam and downstream to Aba Samuel lake inlet which stretches for about $43 \mathrm{~km}$.

\section{Sampling}

Water sample in LAR was collected bi-monthly for physico-chemical and heavy metal constituents in LAR from April 2018 to March 2019 during dry and wet seasons. The sample collection for the wet season was event-based where samples were collected following the rainfall. A total of 22 monitoring stations were selected (Fig. 1); 15 on the main river channel and 7 from tributaries (LART). The sample site selection was based on the factors such as availability of point and nonpoint sources, land use type, nature of anthropogenic influences, accessibility, level of disturbance and type of settlement. Sample collection, handling, preservation, and treatment were according to [21]. A 1.5 L PE bottle was used to collect water for physico-chemical analysis. The bottles were washed by deionized water 24 hours prior to sample collection and rinsed three times by sample water during collection. Once collected, the samples were preserved, put in the cooler box (Mobicool v30 AC/DC, Germany) and transported immediately to the laboratory for analysis.

\section{Analytical Methods}

The collected samples were analyzed for 11 physico-chemical parameters, namely, $\mathrm{pH}$, Electrical Conductivity (EC), Total Dissolved Solids (TDS), Water Temperature (T), Dissolved Oxygen (DO), 5-days Biochemical Oxygen Demand $\left(\mathrm{BOD}_{5}\right)$, Chemical Oxygen Demand (COD), Total Kjeldahl Nitrogen $(\mathrm{TKN})$, Nitrate $\left(\mathrm{NO}_{3}-\mathrm{N}\right)$, Nitrite $\left(\mathrm{NO}_{2}-\mathrm{N}\right)$,

Table 1. Analyzed parameters and analytical methods.

\begin{tabular}{|c|c|c|c|c|}
\hline No. & Parameter & Measurement Location & Analytical Method & Instrument \\
\hline 1 & $\mathrm{pH}$ & On site & Digital Multi-parameter analyzer & HQ40d, USA \\
\hline 2 & DO & On site & Digital Multi-parameter analyzer & HQ40d, USA \\
\hline 3 & $\mathrm{EC}$ & On site & Digital Multi-parameter analyzer & HQ40d, USA \\
\hline 4 & TDS & On site & Digital Multi-parameter analyzer & HQ40d, USA \\
\hline 5 & Temperature & On site & Digital Multi-parameter analyzer & HQ40d, USA \\
\hline 6 & BOD & Laboratory & Modified Winkler & \\
\hline 7 & COD & Laboratory & Open Reflex & \\
\hline 8 & Orthophosphate & Laboratory & Spectrophotometer & DR2800 (HACH, USA) \\
\hline 9 & TKN & Laboratory & Kjeldahl & Kjeldahl \\
\hline 10 & Nitrate & Laboratory & Spectrophotometer & UV-VIS Spectr., India \\
\hline 11 & Nitrite & Laboratory & Spectrophotometer & DR2800 (HACH, USA) \\
\hline 12 & Heavy Metals & Laboratory & GFAAS & \\
\hline
\end{tabular}

All units in mg/L except pH (s.u), Temp $\left({ }^{\circ} \mathrm{C}\right), \mathrm{EC}(\mu \mathrm{S} / \mathrm{cm})$ 
Orthophosphate $\left(\mathrm{PO}_{4}-\mathrm{P}\right)$ and heavy metals such as Manganese (Mn), Chromium (Cr), Lead (Pb), Zinc (Zn), Copper $(\mathrm{Cu})$, and Cadmium $(\mathrm{Cd})$. All the analytical procedures (Table 1) for the determination of physicochemical and heavy metals constituents of the LAR are according to $[21,22]$.

\section{Statistical Analysis}

Data treatment needs to be performed for constituents with non-detects, outliers, retaining, and deletion, and exclusion of monitored water quality data prior to the implementation of MSTs. For effective interpretation of water quality variables by FA, redundant parameters need to be excluded so that the information explained by PCA/FA will not be distorted [23]. In addition, data normalization and standardization are also prerequisites during MST analysis so as to control bias during evaluation [24]. For the case of LAR, the raw water quality data were tested for normality and checked for outliers. The variables were further Z-scale standardized to have standard deviation of one and a mean of zero. With Z-standardization, some parameters with different measurement units will have a similar weight to others and the impact of parameters with unjustified influence will be avoided $[25,26]$. A parametric test, one-way ANOVA, was performed on raw data to check the availability of a significant difference between the sample means. In LAR, FA was used to qualitatively determine the type of source contributing for LAR pollution where data quality plays a vital role while analyzing the water quality constituents. Hence, prior to FA, the suitability of the collected samples for FA was checked using the parameters suitability test: Kaiser-Meyer-Olkin (KMO), a measure of sampling adequacy and Bartlett's test of sphericity that on the other hand examines whether the available data are independent or not. A KMO value close to unity would generally mean the correlations are compacted and hence the sampling and the samples are highly suitable for FA whereas smaller values would generally mean that the variables in consideration have very little in common [24]. Though KMO greater than 0.5 is considered adequate [27, 28], higher values are often recommended. On the other hand, CA was used to group all the monitoring station according to their spatial similarity were Hierarchical Cluster Analysis (HCA) was used to classify the monitoring stations based on the similarity between constituents through Ward's method. The statistical analysis in this paper was performed integrally by R (v3.5.3), PAST, and Microsoft Excel (2016).

\section{Multivariate Receptor Model (UNMIX) and Its Application in LAR}

Although MSTs are nowadays gaining advantages as they can predict the type of source contributing to river pollution, quantifying constituent contribution is often difficult [12]. MRMs, developed based on the mathematical procedure in consideration of sources contribution of constituents, have now become successful to fill this gap. Many studies were conducted integrating MRMs such as PMF and UNMIX [14], APCS-MLR and PMF [29, 30] or individual model such as UNMIX [13], APCS-MLR [12, 31] to estimate the contribution of a certain source to each individual constituent based on the source type identified. EPA's UNMIX model has become popular among MRMs in recent days to review environmental sample data such as air, water quality and sediment analysis [32]. The UNMIX model primarily assumes the constituent concentration has a linear relationship with a certain source of unknown number and contribution where both remain positive [33]. Whereas the source contribution explains the share of each source for individual constituents, the source type is determined based on the constituents' source profile [32].

\section{Results and Discussion}

\section{Evaluation of Spatio-Temporal Variation of Water Quality in LAR}

Descriptive statistics for physico-chemical characteristics of LAR for the dry season is shown on Table 2. A physical water quality parameter, $\mathrm{pH}$, in LAR during the wet season has shown few irregularities across the monitoring stations. The monitored $\mathrm{pH}$ on LAR ranged from 7.1-7.97 were the minimum 7.1 recorded at two of the tributaries; T1 and T4, where both receive domestic waste including raw sewage from residential areas. Though deviation of $\mathrm{pH}$ from the recommended standard limit could have impact on the aquatic environment [4], the observed $\mathrm{pH}$ in LAR was within the national standard [34] . On the other hand, maximum $\mathrm{pH}$ was recorded at M13 with 7.97 where the effluent released from the wastewater treatment plant upstream of the monitoring station could be a contributing factor for the rise in $\mathrm{pH}$. Unlike the wet season, the $\mathrm{pH}$ recorded during the dry season showed deviation from the standard guideline at M3. The lower $\mathrm{pH}$ at station M3 (5.7) could be due to the presence of acidic waste released from the most polluted segment of the river originating from densely populated urban commercial center, Merkato.

The DO concentration in river is the major controlling factor for the existence of aquatic life [35]. In LAR, DO concentration rises during the wet season due to increased flow and physical aeration by river wave action. The DO trend in the LAR monitoring stations during the wet season was found that the concentration in the upstream section of the river had few deviations from the standard guideline relative to the middle catchment. This could primarily be due to the availability of fewer industries and relatively less anthropogenic influence. On the other hand, LAR 
Table 2. Descriptive statistics of spatial variation in LAR physico-chemical constituents during the dry season: mean and standard deviation (in bracket, italics).

\begin{tabular}{|c|c|c|c|c|c|c|c|c|c|c|c|}
\hline St. & $\mathrm{PO}_{4}-\mathrm{P}$ & $\mathrm{NO}_{2}-\mathrm{N}$ & COD & BOD & DO & $\mathrm{pH}$ & TDS & Temp & TKN & $\mathrm{NO}_{3}-\mathrm{N}$ & $\mathrm{EC}$ \\
\hline M1 & $\begin{array}{c}5.5 \\
(1.3)\end{array}$ & $\begin{array}{c}0.06 \\
(0.02)\end{array}$ & $\begin{array}{l}1146 \\
(106)\end{array}$ & $\begin{array}{l}101.2 \\
(80.9)\end{array}$ & $\begin{array}{l}1.53 \\
(0.3)\end{array}$ & $\begin{array}{c}7.2 \\
(0.08)\end{array}$ & $\begin{array}{l}502 \\
(74)\end{array}$ & $\begin{array}{l}12.8 \\
(0.5)\end{array}$ & $\begin{array}{l}28.2 \\
(4.8)\end{array}$ & $\begin{array}{c}0.35 \\
(0.09)\end{array}$ & $\begin{array}{l}1022 \\
\text { (133) }\end{array}$ \\
\hline M2 & $\begin{array}{c}4.5 \\
(0.03)\end{array}$ & $\begin{array}{c}0.07 \\
(0.03)\end{array}$ & $\begin{array}{c}912 \\
(308)\end{array}$ & $\begin{array}{l}110.8 \\
(30.5)\end{array}$ & $\begin{array}{c}3.2 \\
(0.44)\end{array}$ & $\begin{array}{c}7.3 \\
(0.02)\end{array}$ & $\begin{array}{l}440.8 \\
(39.5)\end{array}$ & $\begin{array}{l}12.9 \\
(0.4)\end{array}$ & $\begin{array}{l}40.8 \\
(6.2)\end{array}$ & $\begin{array}{c}0.23 \\
(0.17)\end{array}$ & $\begin{array}{c}899.8 \\
(56)\end{array}$ \\
\hline M3 & $\begin{array}{c}3.02 \\
(2)\end{array}$ & $\begin{array}{c}0.08 \\
0.004\end{array}$ & $\begin{array}{l}1477 \\
(250)\end{array}$ & $\begin{array}{l}582.3 \\
(10.3)\end{array}$ & $\begin{array}{c}0.25 \\
(0.02)\end{array}$ & $\begin{array}{c}5.6 \\
(0.5)\end{array}$ & $\begin{array}{c}699.75 \\
(93)\end{array}$ & $\begin{array}{c}18.7 \\
(0.22)\end{array}$ & $\begin{array}{c}61.6 \\
(16.4)\end{array}$ & $\begin{array}{l}0.74 \\
(0.5)\end{array}$ & $\begin{array}{l}1415 \\
(203)\end{array}$ \\
\hline M4 & $\begin{array}{c}5.2 \\
(0.23)\end{array}$ & $\begin{array}{c}0.11 \\
(0.01)\end{array}$ & $\begin{array}{l}1036 \\
(357)\end{array}$ & $\begin{array}{l}316.4 \\
(98.1)\end{array}$ & $\begin{array}{c}0.12 \\
(0.01)\end{array}$ & $\begin{array}{c}7.2 \\
(0.07)\end{array}$ & $\begin{array}{l}638.2 \\
(52.4)\end{array}$ & $\begin{array}{c}19.8 \\
(0.06)\end{array}$ & $\begin{array}{l}42.2 \\
(3.9)\end{array}$ & $\begin{array}{c}0.92 \\
(0.23)\end{array}$ & $\begin{array}{c}1293.3 \\
(85.7)\end{array}$ \\
\hline M5 & $\begin{array}{c}7.8 \\
(1.62) \\
\end{array}$ & $\begin{array}{c}0.11 \\
(0.02) \\
\end{array}$ & $\begin{array}{l}1442 \\
(355)\end{array}$ & $\begin{array}{l}389.2 \\
(35.9)\end{array}$ & $\begin{array}{c}0.11 \\
(0.01)\end{array}$ & $\begin{array}{c}7.2 \\
(0.2) \\
\end{array}$ & $\begin{array}{l}724.2 \\
(38.8) \\
\end{array}$ & $\begin{array}{c}19.7 \\
(0.08) \\
\end{array}$ & $\begin{array}{l}44.6 \\
(2.4) \\
\end{array}$ & $\begin{array}{c}0.72 \\
(0.22) \\
\end{array}$ & $\begin{array}{c}1464 \\
(42.5) \\
\end{array}$ \\
\hline M6 & $\begin{array}{c}5.5 \\
(0.6)\end{array}$ & $\begin{array}{c}0.06 \\
(0.02)\end{array}$ & $\begin{array}{l}1260 \\
(409)\end{array}$ & $\begin{array}{c}481 \\
(104)\end{array}$ & $\begin{array}{c}2.06 \\
(0.53)\end{array}$ & $\begin{array}{c}6.9 \\
(0.24)\end{array}$ & $\begin{array}{l}481.8 \\
(31.3)\end{array}$ & $\begin{array}{c}16.2 \\
(0.21)\end{array}$ & $\begin{array}{c}84.1 \\
(12.1)\end{array}$ & $\begin{array}{c}0.4 \\
(0.12)\end{array}$ & $\begin{array}{c}984 \\
(29.3)\end{array}$ \\
\hline M7 & $\begin{array}{c}3.96 \\
(1)\end{array}$ & $\begin{array}{c}0.03 \\
(0.02)\end{array}$ & $\begin{array}{c}771 \\
(344) \\
\end{array}$ & $\begin{array}{l}180.4 \\
(104)\end{array}$ & $\begin{array}{c}4.8 \\
(0.84)\end{array}$ & $\begin{array}{c}7.5 \\
(0.4) \\
\end{array}$ & $\begin{array}{l}514.5 \\
(80.7)\end{array}$ & $\begin{array}{c}15.8 \\
(0.13) \\
\end{array}$ & $\begin{array}{l}40.6 \\
(5.4)\end{array}$ & $\begin{array}{c}0.37 \\
(0.06)\end{array}$ & $\begin{array}{c}1046.8 \\
(142)\end{array}$ \\
\hline M8 & $\begin{array}{c}1.2 \\
(0.1) \\
\end{array}$ & $\begin{array}{c}0.01 \\
0.001\end{array}$ & $\begin{array}{l}1078 \\
(403) \\
\end{array}$ & $\begin{array}{l}139.2 \\
(10.1)\end{array}$ & $\begin{array}{c}2.9 \\
(0.43) \\
\end{array}$ & $\begin{array}{c}6.8 \\
(0.06) \\
\end{array}$ & $\begin{array}{r}634.5 \\
(117) \\
\end{array}$ & $\begin{array}{c}21.1 \\
(0.77) \\
\end{array}$ & $\begin{array}{l}27.6 \\
(1.6) \\
\end{array}$ & $\begin{array}{c}1.8 \\
(0.43) \\
\end{array}$ & $\begin{array}{l}1286 \\
(218) \\
\end{array}$ \\
\hline M9 & $\begin{array}{c}3.9 \\
(0.2) \\
\end{array}$ & $\begin{array}{c}0.04 \\
(0.02)\end{array}$ & $\begin{array}{l}1467 \\
(554) \\
\end{array}$ & $\begin{array}{l}284.8 \\
(98.8) \\
\end{array}$ & $\begin{array}{c}0.14 \\
(0.03)\end{array}$ & $\begin{array}{c}6.9 \\
(0.08) \\
\end{array}$ & $\begin{array}{l}677.8 \\
(84.2) \\
\end{array}$ & $\begin{array}{c}20.7 \\
(1.02)\end{array}$ & $\begin{array}{l}43.8 \\
(1.4) \\
\end{array}$ & $\begin{array}{c}0.94 \\
(0.33)\end{array}$ & $\begin{array}{l}1380 \\
(164)\end{array}$ \\
\hline M10 & $\begin{array}{l}4.99 \\
(0.7)\end{array}$ & $\begin{array}{c}0.07 \\
(0.01)\end{array}$ & $\begin{array}{l}1112 \\
(515)\end{array}$ & $\begin{array}{c}161.4 \\
\text { (71) }\end{array}$ & $\begin{array}{c}0.36 \\
(0.02)\end{array}$ & $\begin{array}{c}7.2 \\
(0.2)\end{array}$ & $\begin{array}{l}641.5 \\
(51.4)\end{array}$ & $\begin{array}{c}19.2 \\
(0.42)\end{array}$ & $\begin{array}{c}55.4 \\
(13.5)\end{array}$ & $\begin{array}{c}1.33 \\
(0.68)\end{array}$ & $\begin{array}{r}1300.3 \\
(93.2)\end{array}$ \\
\hline M11 & $\begin{array}{c}5.3 \\
(0.2) \\
\end{array}$ & $\begin{array}{c}0.03 \\
0.006 \\
\end{array}$ & $\begin{array}{c}988 \\
(332) \\
\end{array}$ & $\begin{array}{r}117.1 \\
(7.9) \\
\end{array}$ & $\begin{array}{c}0.2 \\
(0.1) \\
\end{array}$ & $\begin{array}{c}7.3 \\
(0.17) \\
\end{array}$ & $\begin{array}{l}638.2 \\
(46.1) \\
\end{array}$ & $\begin{array}{l}19.4 \\
(0.7) \\
\end{array}$ & $\begin{array}{c}85 \\
(21.6) \\
\end{array}$ & $\begin{array}{c}1.3 \\
(0.41) \\
\end{array}$ & $\begin{array}{r}1294.3 \\
(79.9) \\
\end{array}$ \\
\hline M12 & $\begin{array}{c}6.3 \\
(1.7) \\
\end{array}$ & $\begin{array}{c}0.27 \\
(0.22) \\
\end{array}$ & $\begin{array}{l}1056 \\
(402) \\
\end{array}$ & $\begin{array}{l}129.7 \\
(38.9) \\
\end{array}$ & $\begin{array}{c}0.1 \\
(0.04) \\
\end{array}$ & $\begin{array}{c}7.6 \\
(0.05) \\
\end{array}$ & $\begin{array}{l}665.8 \\
(26.8) \\
\end{array}$ & $\begin{array}{l}20.5 \\
(0.8) \\
\end{array}$ & $\begin{array}{c}50 \\
(8.3) \\
\end{array}$ & $\begin{array}{l}0.95 \\
(0.1) \\
\end{array}$ & $\begin{array}{r}1347.5 \\
(20.4)\end{array}$ \\
\hline M13 & $\begin{array}{c}6.7 \\
(1.4) \\
\end{array}$ & 0.084 & $\begin{array}{l}1011 \\
(488) \\
\end{array}$ & $\begin{array}{l}117.1 \\
(12.9)\end{array}$ & $\begin{array}{c}1.02 \\
(0.23) \\
\end{array}$ & $\begin{array}{c}7.6 \\
(0.03) \\
\end{array}$ & $\begin{array}{l}685.5 \\
(57.4) \\
\end{array}$ & $\begin{array}{c}19.8 \\
(0.33) \\
\end{array}$ & $\begin{array}{c}38.8 \\
(1.35) \\
\end{array}$ & $\begin{array}{c}0.82 \\
(0.22) \\
\end{array}$ & $\begin{array}{r}1387.5 \\
(81.9)\end{array}$ \\
\hline M14 & $\begin{array}{l}6.63 \\
(1.1) \\
\end{array}$ & $\begin{array}{c}0.05 \\
(0.02) \\
\end{array}$ & $\begin{array}{l}1076 \\
(427)\end{array}$ & $\begin{array}{c}63.3 \\
(25.9)\end{array}$ & $\begin{array}{c}0.8 \\
(0.4) \\
\end{array}$ & $\begin{array}{c}7.5 \\
(0.03) \\
\end{array}$ & $\begin{array}{l}692.5 \\
(80.9) \\
\end{array}$ & $\begin{array}{c}21.4 \\
(0.21)\end{array}$ & $\begin{array}{l}43.3 \\
(3.1)\end{array}$ & $\begin{array}{c}1.05 \\
(0.35) \\
\end{array}$ & $\begin{array}{c}1401.5 \\
(129)\end{array}$ \\
\hline M15 & $\begin{array}{l}0.36 \\
(0.1) \\
\end{array}$ & $\begin{array}{c}0.3 \\
(0.08) \\
\end{array}$ & $\begin{array}{c}594 \\
(290) \\
\end{array}$ & $\begin{array}{l}60.1 \\
(10) \\
\end{array}$ & $\begin{array}{c}5.8 \\
(0.8) \\
\end{array}$ & $\begin{array}{c}7.6 \\
(0.11) \\
\end{array}$ & $\begin{array}{l}224.6 \\
(37.3)\end{array}$ & $\begin{array}{c}13.1 \\
(0.26) \\
\end{array}$ & $\begin{array}{c}12.5 \\
(0.96) \\
\end{array}$ & $\begin{array}{c}0.2 \\
(0.09) \\
\end{array}$ & $\begin{array}{l}464.8 \\
(52.5)\end{array}$ \\
\hline $\mathrm{T} 2$ & $\begin{array}{l}2.09 \\
(1.9) \\
\end{array}$ & $\begin{array}{c}0.33 \\
(0.27) \\
\end{array}$ & $\begin{array}{l}506.8 \\
(154) \\
\end{array}$ & $\begin{array}{c}70.8 \\
(75.2) \\
\end{array}$ & $\begin{array}{c}5.2 \\
(0.72) \\
\end{array}$ & $\begin{array}{c}7.7 \\
(0.32) \\
\end{array}$ & $\begin{array}{l}358.3 \\
(71.1) \\
\end{array}$ & $\begin{array}{c}18.6 \\
(0.91) \\
\end{array}$ & $\begin{array}{c}26.1 \\
(15.7) \\
\end{array}$ & $\begin{array}{c}0.27 \\
(0.02) \\
\end{array}$ & $\begin{array}{r}749.8 \\
(131) \\
\end{array}$ \\
\hline $\mathrm{T} 4$ & $\begin{array}{c}8.7 \\
(6.3)\end{array}$ & $\begin{array}{c}0.08 \\
(0.03)\end{array}$ & $\begin{array}{l}1167 \\
(280)\end{array}$ & $\begin{array}{c}518 \\
(150)\end{array}$ & $\begin{array}{c}0.14 \\
(0.04)\end{array}$ & $\begin{array}{c}7.2 \\
(0.15)\end{array}$ & $\begin{array}{c}877 \\
(138)\end{array}$ & $\begin{array}{c}24 \\
(0.83)\end{array}$ & $\begin{array}{c}70.5 \\
(23.5)\end{array}$ & $\begin{array}{c}0.17 \\
(0.13)\end{array}$ & $\begin{array}{c}1704.7 \\
(253)\end{array}$ \\
\hline $\mathrm{T} 3$ & $\begin{array}{l}14.5 \\
(2.9) \\
\end{array}$ & $\begin{array}{c}0.15 \\
(0.03) \\
\end{array}$ & $\begin{array}{l}1697 \\
(502) \\
\end{array}$ & $\begin{array}{c}520 \\
(126) \\
\end{array}$ & $\begin{array}{c}0.14 \\
(0.05) \\
\end{array}$ & $\begin{array}{c}7 \\
(0.18) \\
\end{array}$ & $\begin{array}{r}821.3 \\
(115) \\
\end{array}$ & $\begin{array}{c}20.8 \\
(0.93) \\
\end{array}$ & $\begin{array}{c}129 \\
(32.4) \\
\end{array}$ & $\begin{array}{c}0.1 \\
(0.08) \\
\end{array}$ & $\begin{array}{c}1601.7 \\
(212) \\
\end{array}$ \\
\hline $\mathrm{T} 7$ & $\begin{array}{l}1.37 \\
(0.7) \\
\end{array}$ & $\begin{array}{c}0.35 \\
(0.46)\end{array}$ & $\begin{array}{l}310.5 \\
(187)\end{array}$ & $\begin{array}{c}82.3 \\
(50.9) \\
\end{array}$ & $\begin{array}{c}3.54 \\
(1.27) \\
\end{array}$ & $\begin{array}{c}7.2 \\
(0.25) \\
\end{array}$ & $\begin{array}{l}364.8 \\
(41.9)\end{array}$ & $\begin{array}{c}19.1 \\
(1.11)\end{array}$ & $\begin{array}{l}30.3 \\
(8.5) \\
\end{array}$ & $\begin{array}{c}0.03 \\
(0.01) \\
\end{array}$ & $\begin{array}{l}761.7 \\
(77.1)\end{array}$ \\
\hline $\mathrm{T} 1$ & $\begin{array}{l}4.76 \\
(2) \\
\end{array}$ & $\begin{array}{c}0.07 \\
(0.05) \\
\end{array}$ & $\begin{array}{l}656.5 \\
(460) \\
\end{array}$ & $\begin{array}{l}127.7 \\
(97.7) \\
\end{array}$ & $\begin{array}{c}1.35 \\
(1.11) \\
\end{array}$ & $\begin{array}{c}7.1 \\
(0.2) \\
\end{array}$ & $\begin{array}{l}412.8 \\
(36.1) \\
\end{array}$ & $\begin{array}{c}16.9 \\
(0.95) \\
\end{array}$ & $\begin{array}{l}42.9 \\
(16) \\
\end{array}$ & $\begin{array}{c}0.17 \\
(0.15) \\
\end{array}$ & $\begin{array}{l}850.1 \\
(66.4) \\
\end{array}$ \\
\hline T5 & $\begin{array}{c}5.2 \\
(0.9) \\
\end{array}$ & $\begin{array}{c}0.09 \\
(0.04)\end{array}$ & $\begin{array}{l}497.3 \\
(222) \\
\end{array}$ & $\begin{array}{l}94.5 \\
(104)\end{array}$ & $\begin{array}{c}0.95 \\
(0.98)\end{array}$ & $\begin{array}{c}7.4 \\
(0.18) \\
\end{array}$ & $\begin{array}{c}496 \\
(57.2) \\
\end{array}$ & $\begin{array}{c}23.7 \\
(1.49)\end{array}$ & $\begin{array}{c}33.1 \\
(3.26)\end{array}$ & $\begin{array}{c}0.16 \\
(0.14) \\
\end{array}$ & $\begin{array}{c}1003.2 \\
(105)\end{array}$ \\
\hline T6 & $\begin{array}{c}4 \\
(1.4) \\
\end{array}$ & $\begin{array}{c}0.08 \\
(0.01)\end{array}$ & $\begin{array}{l}440.3 \\
(150)\end{array}$ & $\begin{array}{l}112.4 \\
(78.5)\end{array}$ & $\begin{array}{c}0.22 \\
(0.06)\end{array}$ & $\begin{array}{c}7.7 \\
(0.21)\end{array}$ & $\begin{array}{l}584.8 \\
(51.3)\end{array}$ & $\begin{array}{c}24.8 \\
(1.42)\end{array}$ & $\begin{array}{c}96.6 \\
(64.6)\end{array}$ & $\begin{array}{c}0.24 \\
(0.09)\end{array}$ & $\begin{array}{r}1166.5 \\
(94.4)\end{array}$ \\
\hline
\end{tabular}

All units in mg/L except $\mathrm{pH}(\mathrm{s} . \mathrm{u})$, Temp (oC), EC ( $\mu \mathrm{S} / \mathrm{cm}), \mathrm{M}=$ Main Channel, T=Tributary, St.=Station (code)

tributaries, mostly in the middle catchment, has shown high DO deterioration were $0.79 \mathrm{mg} / \mathrm{L}$ is recorded at T3, the most polluted tributary of LAR. The higher DO concentration was recorded at M15 (7.07) and M7 (7.06) $\mathrm{mg} / \mathrm{L}$ respectively. Both stations are located at the upstream and less disturbed section of the catchment, the later found at a closer range downstream from a waterfall that could initiate the re-oxygenation. The average DO concentration in LAR tributaries during the wet season is nearly $3.88 \mathrm{mg} / \mathrm{L}$ whereas the main 
channel is about $5.39 \mathrm{mg} / \mathrm{L}$. The overall mean DO in the LAR during the rainy season was $4.91 \mathrm{mg} / \mathrm{L}$. Though DO is considered very essential in sustaining life in the river, its concentration in LAR revealed that the river is very much polluted so that it is not suitable for any purpose during the dry season. The middle catchment of LAR is highly impacted by this low flow and hence had high DO deterioration. Almost all of the stations didn't meet either the Ethiopian or international standards for aquatic life. The study conducted on similar area by Yilma et.al. [17] also showed that nearly $89 \%$ of the monitored stations analyzed on LAR during the dry season had DO concentration less than $4 \mathrm{mg} / \mathrm{L}$ whereas the current assessment showed $82 \%$ indicating the river is severely polluted.

The EC, a proxy measure of salt concentration, is found very high in LAR with a mean value of 660.4 $( \pm 282.25) \mu \mathrm{S} / \mathrm{cm}$ recorded during the wet season indicating the severity of the river pollution. The TDS in the river on the other hand, was found in high amount with a mean value of $325.3( \pm 141.48) \mathrm{mg} / \mathrm{L}$. The high standard deviation in both parameters could imply that the characteristics of both constituents vary spatially [17] and seasonally [10]. Both EC and TDS were recorded highest in the LAR tributaries located in the highly polluted segment of the river that could be attributed due to the presence of inorganic salts [4]. EC during the wet season has shown strong positive correlation with BOD $(\mathrm{r}=0.87)$, negative with DO $(\mathrm{r}=-0.83)$, and positive with PO4-P $(r=0.70)$ at a significance level $\mathrm{p}<0.01$. Unlike the wet season, EC and TDS during the dry season recorded high in almost all monitoring stations in general and LART in particular, with a mean value of $1142.5 \mu \mathrm{S} / \mathrm{cm}$ and $565.7 \mathrm{mg} / \mathrm{L}$ respectively. In most of the monitoring stations of LAR, the water temperature has shown slight increment from upstream to the downstream section of the main river, though there are a few irregularities at some monitoring stations from the trend during the wet season. The mean temperature in the LAR is found to be $19 \pm 2.18^{\circ} \mathrm{C}$. The minimum and maximum temperatures were recorded at M2 and T4 respectively. In general, the LAR tributaries recorded the highest temperature than the main channel. The temperature in LAR has a very weak correlation with other parameters except for TKN $(r=0.57)$. The trend in water temperature during the dry season has shown nearly similar distribution across the river stretch where the lowest was recorded at station M1 and maximum at T6. COD and BOD measures the organic contamination load and indicates the pollution level in a river [10]. During the wet season, the LAR main channel has a nearly similar trend of $\mathrm{BOD}_{5}$ across the monitoring station, whereas the variation in concentration among the monitoring stations in LART was significantly high. The mean $\mathrm{BOD}_{5}$ concentration in LAR is $46.79 \mathrm{mg} / \mathrm{L}$ where minimum and maximum $\mathrm{BOD}_{5}$ concentration of $2.5 \mathrm{mg} / \mathrm{L}$ and $130.324 \mathrm{mg} / \mathrm{L}$ were recorded at T7 and M3 respectively. Similarly, the mean COD concentration of LAR for the wet season is $266.9 \mathrm{mg} / \mathrm{L}$ with the highest recorded at two of the LARTs: T4 and T3 with a mean concentration of 552 and $520 \mathrm{mg} / \mathrm{L}$ respectively. Both BOD and COD concentration has shown high deviation from Ethiopian [34] and WHO [36] guideline for aquatic life on some of the stations and have strong positive correlation during the rainy season $(\mathrm{r}=0.76)$ and dry season $(\mathrm{r}=0.81)$. The highest $\mathrm{BOD}_{5}$ and COD concentration recorded during the dry season is due to the reduced flow in the river that minimizes the dilution and selfpurification of LAR. Apart from the organic pollutants, nutrients play a vital role in the pollution of LAR. A nitrate concentration up to $10 \mathrm{mg} / \mathrm{L}$ in natural water bodies where the concentration in excess amount may affect the river ecology [10]. However, nitrate concentration in LAR during the rainy season is within the guideline standard of Ethiopia [34]. The mean concentration of $\mathrm{NO}_{3}-\mathrm{N}$ in the LAR main channel and tributaries respectively are $0.424 \mathrm{mg} / \mathrm{L}$ and $0.856 \mathrm{mg} / \mathrm{L}$, the tributary exceeding the main channel two folds. On the other hand, mean nitrite concentration in the seven monitored LARTs $(0.441 \mathrm{mg} / \mathrm{L})$ is slightly lower than the concentration in the main channel $(0.892 \mathrm{mg} / \mathrm{L})$. On the other hand, the mean concentration of TKN in the tributaries during wet season was $32.4 \mathrm{mg} / \mathrm{L}$ where the monitoring station at T6 has recorded the highest $(61.2 \mathrm{mg} / \mathrm{L})$. The stations downstream of M4 and near M13 downstream of Addis Ababa wastewater treatment plant have the highest TKN concentration with a mean value of $32.2 \mathrm{mg} / \mathrm{L}$ each. The TKN during the dry season has shown an increasing trend relative to the wet season. The station M3 (129.3 mg/L) has shown the highest concentration of TKN. The phosphate during the wet season has recorded the highest on LARTs. Less variation of phosphate concentration has been observed across the monitoring stations. The maximum concentration of phosphate was recorded at T5 where the river receives waste from the slaughterhouse where the animal bone and small scale urban agricultural washouts remain the major source of phosphate in the area. The phosphate concentration during the dry season has shown an increasing trend where the middle of LART at T3 recorded the maximum phosphate concentration at $15.65 \mathrm{mg} / \mathrm{L}$. Phosphate concentration at M5 could suggest that the wastewater released from the slaughter house could be the possible source for the high concentration.

Heavy metal concentrations in LAR and LART has shown much higher concentration than the national [34] and international guideline values for industrial release to a water body at most of the monitoring stations. Analysis of $\mathrm{Ni}$ in LAR has shown $67 \%$ and $100 \%$ of non-detects during the rainy and dry seasons respectively. Among the trace metals analyzed during the monitoring campaign for the rainy and dry season, $\mathrm{Cr}$ has shown the maximum concentration relative to other metals with a mean concentration of 2.175 $\mathrm{mg} / \mathrm{L}$ and $1.17 \mathrm{mg} / \mathrm{L}$ respectively. This could be due 
to the presence of most tanneries and textile industries near the river. The maximum $\mathrm{Cr}$ concentration during the rainy season was recorded downstream of M12 $(2.175 \mathrm{mg} / \mathrm{L})$. The highest $\mathrm{Mn}$ concentration was observed at the station near M13 $(0.93 \mathrm{mg} / \mathrm{L})$ followed by the monitoring station at M11 $(0.87 \mathrm{mg} / \mathrm{L})$. The distribution of $\mathrm{Zn}$ concentration along the LAR has shown slight irregularity across the monitoring stations during both seasons. LAR monitoring station M1 $(0.62 \mathrm{mg} / \mathrm{L})$ and T3 $(0.42 \mathrm{mg} / \mathrm{L})$ were found to be the highest $\mathrm{Zn}$ concentration during the rainy and dry season respectively. The mean concentration of $\mathrm{Zn}$ is found to be $0.227 \mathrm{mg} / \mathrm{L}$. Cadmium $(\mathrm{Cd})$, which originates mostly from anthropogenic activities through the application of phosphate fertilizer, has shown almost a constant trend across the monitoring stations. The mean concentration of $\mathrm{Cd}$ during the rainy season and the dry season is found to be $0.0093 \mathrm{mg} / \mathrm{L}$ and $0.116 \mathrm{mg} / \mathrm{L}$ respectively. The concentration of heavy metals during the wet season in the order of $\mathrm{Cr}>\mathrm{Mn}>\mathrm{Cu}>\mathrm{Pb}>\mathrm{Zn}>\mathrm{Cd}$ whereas in the dry season the order was $\mathrm{Cr}>\mathrm{Mn}>\mathrm{Cu}>\mathrm{Zn}>\mathrm{Pb}>\mathrm{Cd}$.

\section{Factor Analysis and Seasonal Source Apportionment in LAR}

Factor Analysis has long been widely used in water quality assessment for identifying the most influential and significant parameter from a set of constituents by minimizing the constituents' dimensions without much loss of information contained in the original data [17]. In order to interpret water quality data using the PCA/FA, the data collected need to be checked for suitability for FA. The adequacy of the PCA/FA in LAR was tested based on the KMO, where it is recommended to be greater than 0.5. In LAR, however, the KMO was found to be 0.728 and 0.725 for the wet and dry seasons respectively $(p<0.05)$ showing the suitability of FA for interpreting LAR water quality.

For the FA in LAR, extraction was done by principal components using correlation matrix analysis based on eigenvalues greater than one and varimax rotation. The Kaiser normalization was used for maximizing the variance and extraction of underlining factors called varifactors. A similar approach was followed by $[27,37]$. The loading by constituents of the principal components (PCs) extracted by the FA determines the weight of the respective parameter for the component and would generally indicate the correlation between the variable and the component. According to Cid et al. [5] and Kilonzo et al. [9], component loadings $>0.75$, 0.5-0.75 and 0.3-0.5 are classified as strong, moderate, and weak loading respectively. The FA in LAR extracted three factors by retaining the PCs through varimax rotation that explained $79.26 \%$ of total variance for the wet season. The first factor that explained $37.9 \%$ of total variance after the varimax rotation has strong positive loading for COD (0.96), BOD (0.844), EC (0.775) and TDS (0.767) and moderate loading for $\mathrm{DO}, \mathrm{PO}_{4}-\mathrm{P}$, and
$\mathrm{NO}_{3}-\mathrm{N}$. The strong loading of $\mathrm{COD}, \mathrm{BOD}, \mathrm{EC}$, and TDS in $\mathrm{PC}_{1}$ indicate that the possible source of pollution could be due to the combined effect of anthropogenic factors such as the release of untreated urban sewage $[1,31]$ and the presence of organic pollutant constituents from food, detergent, and beverage industries [17]. In addition, high TDS $(325.3 \mathrm{mg} / \mathrm{l})$ and EC $(660.4 \mu \mathrm{S} / \mathrm{cm})$ in LAR might be due to the impact of urban runoff [10] and natural effects such as the dissolution of soil constituents [3]. Therefore, the factor contributing to the first principal component may be named as a combined domestic and unrecognized non-point source, generally a combined anthropogenic factor. The factor is more dominant in the middle catchment and monitoring stations such as M3, M4, T3, and T4 where domestic waste prevails. The second principal component $\left(\mathrm{PC}_{2}\right)$ showed strong loading on temperature (0.9) and TKN (0.79) and moderate negative loading for DO (-0.645) and moderate positive loading for TDS (0.578) explaining $27.5 \%$ of the total variation. The high loadings of Nitrogen on the $\mathrm{PC}_{2}$ suggest that the sources could be nonpoint sources such as agricultural land use, urban drainage, and residential lawns during the rainy season $[1,30]$. Therefore, the component could be named agricultural factor. The last $\mathrm{PC}, \mathrm{PC}_{3}$, has strong positive loadings on $\mathrm{pH}(0.946)$ and strong negative loadings on $\mathrm{NO}_{3}-\mathrm{N}(-0.716)$ explaining the remaining variance of $13.85 \%$. The strong loading on $\mathrm{pH}$ could be due to the prevalence of physical processes and reactions by aquatic plants [38] and acidity impact from different sources [39]. It can be clearly seen that $\mathrm{PC}_{3}$ is more influenced by industrial sources and may be named the acidity factor. This acidity factor is more dominant in the central and downstream of middle section of the LAR where industrial setup dominates.

The FA in LAR for the dry season has extracted three principal components explaining a total variance of $79.47 \%$ and retained three factors. Accordingly, the first factor explained $36.87 \%$ of total variation and has strong loadings on $\mathrm{PO}_{4}-\mathrm{P}, \mathrm{TKN}, \mathrm{TDS}$, and EC with a component loading of $0.851,0.773,0.796$ and 0.778 respectively, indicating dominance of non-point sources such as washouts from agricultural fields and urban land use and can be named agricultural and urban runoff factor. The component has also moderate positive loading on Temperature (0.71) and negative loading on DO (-0.745) that could imply the impact of seasonal variation. Similarly, the second component which is responsible for $23.1 \%$ of the variation during the dry season has a strong negative loading on $\mathrm{pH}$ $(-0.86)$ and strong positive loading on BOD (0.813) and COD (0.762), suggesting biodegradation of organic and inorganic nutrients are negatively impacted by the acidity of the river. The component is more explained by industrial impact and hence can be named industrial (acidity) factor. The third principal component explaining $19.5 \%$ of total variation has strong positive loading on nitrate (0.926) and negative moderate loading on nitrite $(-0.58)$. Though the source of nitrate 
could be various in type, the role of domestic waste is high and hence this component can be best explained by domestic waste source.

The concentrations of heavy metals have shown a very high variation during both seasons where the major source remains industry. Most of the industries within the vicinity of the river are tannery industries known for their $\mathrm{Cr}$ effluent. The tannery industries nearby the LAR release their wastewater to the river with no or minimal treatment. During the dry season, the FA has extracted two factors that explain a total variance of $68.62 \% . \mathrm{Pb}(0.93)$ and $\mathrm{Cr}(0.85)$ in the first component loaded strongly suggesting that sources of heavy metal pollution in LAR is contributed by more than one source. The probable source of $\mathrm{Cr}$ is tannery industries where most of these industries are located near LAR and are discharging their raw waste to the river directly. On the other hand, the location of many garages and heavy machinery maintenance workshops near LAR could initiate the level of $\mathrm{Pb}$ concentration in the river. Hence factor one could be defined by both industrial and lead-acid battery. On the other hand, the second component is composed of two heavy metals: $\mathrm{Mn}$ and $\mathrm{Zn}$ where $\mathrm{Zn}$ loaded negatively that explains $26.47 \%$ of the total variation.

\section{Spatial Analysis of LAR Using Cluster Analysis}

The CA in MSTs is used to classify monitoring stations with similar characteristics into the same group [27, 40]. In LAR, before the CA, raw data was Z-scale standardized and tested for normality of data distribution. The dendrogram showing the grouping of all 22 monitoring stations for the rainy and dry seasons in LAR and LART is shown in Fig. 2. The CA grouped all 22 monitoring stations in three significant clusters for the wet season in LAR (Fig. 2b). Accordingly, the first cluster (Cluster 1) grouped monitoring stations at the downstream and middle section of LAR in one cluster. The stations in this cluster are characterized by relatively moderate to heavily polluted and consist of 13 monitoring sites: M3M6, M8-M14, T5, and T6. The physical location of all the stations in cluster 1 in a similar area suggests that the clustering is reasonably fair.

Cluster 2 consists of seven monitoring stations that are located at the most upstream section of the river and hence are relatively less polluted. The monitoring stations grouped in this cluster are T1, T2, T7, M1, M2, M7, and M15. The last significant cluster, cluster 3 , is composed of two highly polluted tributaries: T4 and T3. Similarly, the CA on LAR identified four significant clusters during the dry season. Cluster 1 grouped monitoring stations downstream of the middle section of LAR consisting of stations such as M4, M5, M8-M14. Cluster 2, however, grouped monitoring stations at the most polluted river section: T3, T4, M3, and M6. Cluster 3 is composed of tributaries from the most upstream section with monitoring stations T2, T7 and M15 in the group which are characterized by less anthropogenic influence. Finally, cluster 4 is composed of upstream monitoring stations: M1, M2, M7, T1, T5, and T6.

\section{Quantification of Source Composition and Contribution in LAR}

For the estimation of pollution contribution and composition of various sources in LAR, we used the UNMIX model for both dry and wet season. In our study, we have performed manual inclusion and exclusion of parameters in UNMIX until parameters with high error became excluded from modeling [33]. As a basic requirement, the UNMIX was run by checking the Noise-to-Signal (N/S) ratio and overall minimum $\mathrm{R}^{2}$ value. The $\mathrm{R}^{2}$ is meant to express the
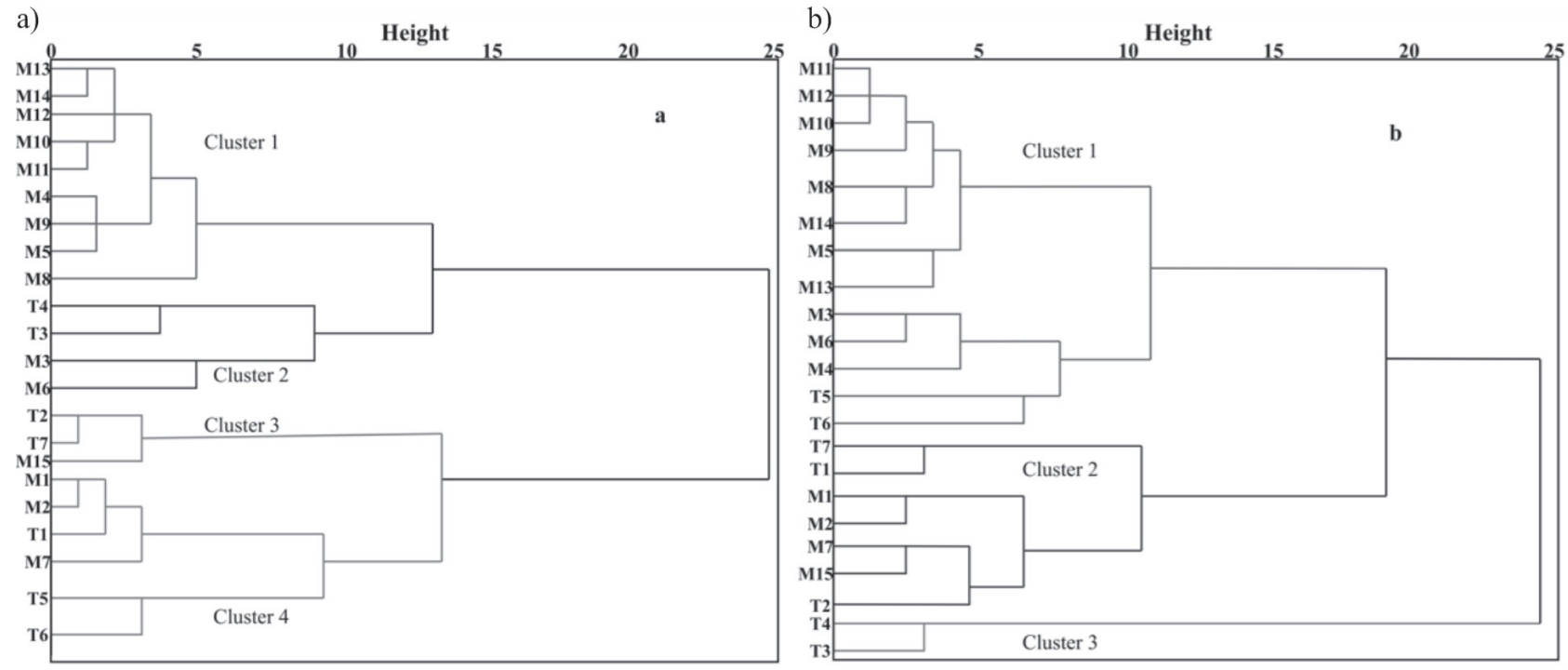

Fig. 2. Dendrogram showing clustering of LAR monitoring stations for dry a) and wet season b). 
Table 3: Source composition and contribution (\%, bracket) of LAR constituents for the dry and wet season.

\begin{tabular}{|c|c|c|c|c|c|c|c|c|}
\hline Parameter & Season & Source1 $\left(\mathrm{S}_{1}\right)$ & Source2 $\left(\mathrm{S}_{2}\right)$ & Source $3\left(\mathrm{~S}_{3}\right)$ & $\mathrm{P}$ & $\mathrm{M}$ & $\mathrm{P} / \mathrm{M}$ & e (\%) \\
\hline \multirow{2}{*}{$\mathrm{PO}_{4}-\mathrm{P}$} & Dry & $0.419(8.4 \%)$ & $1.4(28.1 \%)$ & 3.17 (63.5\%) & 4.989 & 5.02 & 0.994 & -0.62 \\
\hline & Wet & $0.83(35.5 \%)$ & $0.06(2.5 \%)$ & $1.45(61.96 \%)$ & 2.34 & 1.93 & 1.20 & 21.2 \\
\hline \multirow{2}{*}{ COD } & Dry & $78.8(8 \%)$ & $464(47.1 \%)$ & $443(44.9 \%)$ & 985.8 & 986 & 0.99 & -0.02 \\
\hline & Wet & $62.2(18.9 \%)$ & $27(8.2 \%)$ & $240(72.9 \%)$ & 329.2 & 266.9 & 1.23 & 23.3 \\
\hline \multirow{2}{*}{ BOD } & Dry & $0.26(0.11 \%)$ & $53.3(24.2 \%)$ & $167(75.7 \%)$ & 220.6 & 216.4 & 1.1 & 1.9 \\
\hline & Wet & $12.4(20.3 \%)$ & $20.2(33.06 \%)$ & $28.5(46.6 \%)$ & 61.1 & 48.48 & 1.26 & 26.03 \\
\hline \multirow{2}{*}{ DO } & Dry & $7.1(0.11 \%)$ & $34.3(0.535 \%)$ & $58.6(0.914 \%)$ & 1.56 & 1.59 & 0.981 & -1.89 \\
\hline & Wet & $0.2(3.42 \%)$ & $0.51(8.7 \%)$ & $5.14(87.9 \%)$ & 5.85 & 4.91 & 1.2 & 19.9 \\
\hline \multirow{2}{*}{$\mathrm{pH}$} & Dry & $1.93(27.6 \%)$ & $2.86(40.9 \%)$ & $2.2(31.5 \%)$ & 6.99 & 7.22 & 0.97 & -3.2 \\
\hline & Wet & $0.48(6.4 \%)$ & $0.36(4.84 \%)$ & $6.6(88.7 \%)$ & 7.44 & 7.61 & 0.98 & 2.2 \\
\hline \multirow{2}{*}{ TDS } & Dry & $70.4(12.2 \%)$ & $271(46.9 \%)$ & $236(40.9 \%)$ & 577.4 & 580.7 & 0.99 & -0.57 \\
\hline & Wet & $122(33.3 \%)$ & $22(6.01 \%)$ & $222(60.65 \%)$ & 366 & 325.3 & 1.12 & 12.5 \\
\hline \multirow{2}{*}{ Temp } & Dry & $4.25(22.75 \%)$ & $8.01(42.9 \%)$ & $6.42(34.4 \%)$ & 18.68 & 19 & 0.98 & -1.7 \\
\hline & Wet & $2.35(12.6 \%)$ & $1.05(5.6 \%)$ & $15.3(81.82 \%)$ & 18.7 & 19 & 0.98 & -1.6 \\
\hline \multirow{2}{*}{ TKN } & Dry & $5(2.37 \%)$ & $15.3(25.3 \%)$ & $30(72.3 \%)$ & 50.3 & 50.4 & 1 & -0.2 \\
\hline & Wet & $13.2(62 \%)$ & $2.06(9.7 \%)$ & $6.02(28.28 \%)$ & 21.28 & 21 & 1.01 & 1.3 \\
\hline \multirow{2}{*}{$\mathrm{NO}_{3}-\mathrm{N}$} & Dry & $0.007(1.07 \%)$ & $0.599(96.83 \%)$ & $0.013(2.1 \%)$ & 0.619 & 0.602 & 1.03 & 2.8 \\
\hline & Wet & $0.11(15.8 \%)$ & $0.451(64.6 \%)$ & $0.134(19.6 \%)$ & 0.698 & 0.561 & 1.24 & 24.4 \\
\hline \multirow{2}{*}{$\mathrm{EC}$} & Dry & $148(12.7 \%)$ & $552(47.3 \%)$ & $467(40 \%)$ & 1167 & 1173.5 & 0.99 & -0.55 \\
\hline & Wet & $289(38.74 \%)$ & $16(2.14 \%)$ & $441(59.11 \%)$ & 746 & 660.4 & 1.13 & 12.96 \\
\hline \multirow{2}{*}{$\mathrm{NO}_{2}-\mathrm{N}$} & Dry & $0.095(79.8 \%)$ & $0.0031(2.6 \%)$ & $0.021(17.6 \%)$ & 0.119 & 0.117 & 1.02 & 1.71 \\
\hline & Wet & $0.024(2.2 \%)$ & $0.11(10.3 \%)$ & $0.942(87.5 \%)$ & 1.073 & 0.75 & 1.43 & 43.1 \\
\hline
\end{tabular}

All units are in $\mathrm{mg} / \mathrm{L}$ except $\mathrm{pH}$ (s.u.), Temp $\left({ }^{\circ} \mathrm{C}\right), \mathrm{EC}(\mu \mathrm{S} / \mathrm{cm}), \mathrm{P}=$ predicted, $\mathrm{M}=$ measured concentration, $\mathrm{e}=$ error $\mathrm{S}_{1}=$ Agricultural and urban non-point, $\mathrm{S}_{2}=$ Domestic waste, $\mathrm{S}_{3}=$ Industrial waste pollution, for the wet season $\mathrm{S}_{1}=$ Non-point source, $\mathrm{S}_{2}=$ Domestic waste, $\mathrm{S}_{3}=$ Industrial and bio-chemical pollution for the dry season

variance explained by the determined source for each constituent [14]. Accordingly, Min S/N ratio $>2$ and Min $\mathrm{R}^{2}>0.8$ was adopted and the UNMIX model for LAR has fulfilled the minimum requirements with $\min \mathrm{S} / \mathrm{N}$ of 2.71 and $\mathrm{R}^{2}$ of 0.91 for the dry season. With this, $91 \%$ of the variance of each constituent can be explained by three sources namely uncharacterized nonpoint (agricultural and urban runoff), domestic (residential and commercial) and industrial. Similarly, the model output for the rainy season showed $\mathrm{S} / \mathrm{N}$ of 2.16 and $\mathrm{R}^{2}$ of 0.88 explained by three factors: domestic, industrial, and agricultural (nonpoint) pollution.

Source composition by UNMIX in LAR constituents during the dry season has quantified for the three possible sources identified by FA. Table 3 shows percentage source composition and distribution during the wet and dry season calculated by the UNMIX model. In LAR, UNMIX model has effectively predicted the constituents contained in the model with an overall $\mathrm{R}^{2}$ of $99.8 \%$ between the model predicted and observed values, with an average predicted to measured $(\mathrm{P} / \mathrm{M})$ ratio of 1.01 during the dry season and $99.88 \%$ and 1.06 for the wet season. The maximum $\mathrm{CV}$ on the constituents was $16.84 \%$ with a mean $\mathrm{CV}$ of $4.78 \%<25 \%$ showing that the prediction was reasonably good and can be interpreted well. Moreover, the model performance during the dry season is much better than the corresponding rainy season with an average absolute error of $1.38 \%$ when compared to the rainy season $(17.13 \%)$. The model accuracy for individual parameter estimation ranges from good to very good with the $\mathrm{R}^{2}$ value ranging from 0.66 to 0.984 , an example of $\mathrm{NO}_{3}-\mathrm{N}$ with $\mathrm{R}^{2}$ of 0.96 is shown on Fig. 3. The model was relatively weak to capture the $\mathrm{NO}_{2}-\mathrm{N}$ contribution during the rainy season generating $43.1 \%$ error calculated between the predicted and observed concentrations.

From Table 3, it can be clearly seen that the contribution of source 1 (uncharacterized non-point source) for individual constituents is relatively weak 


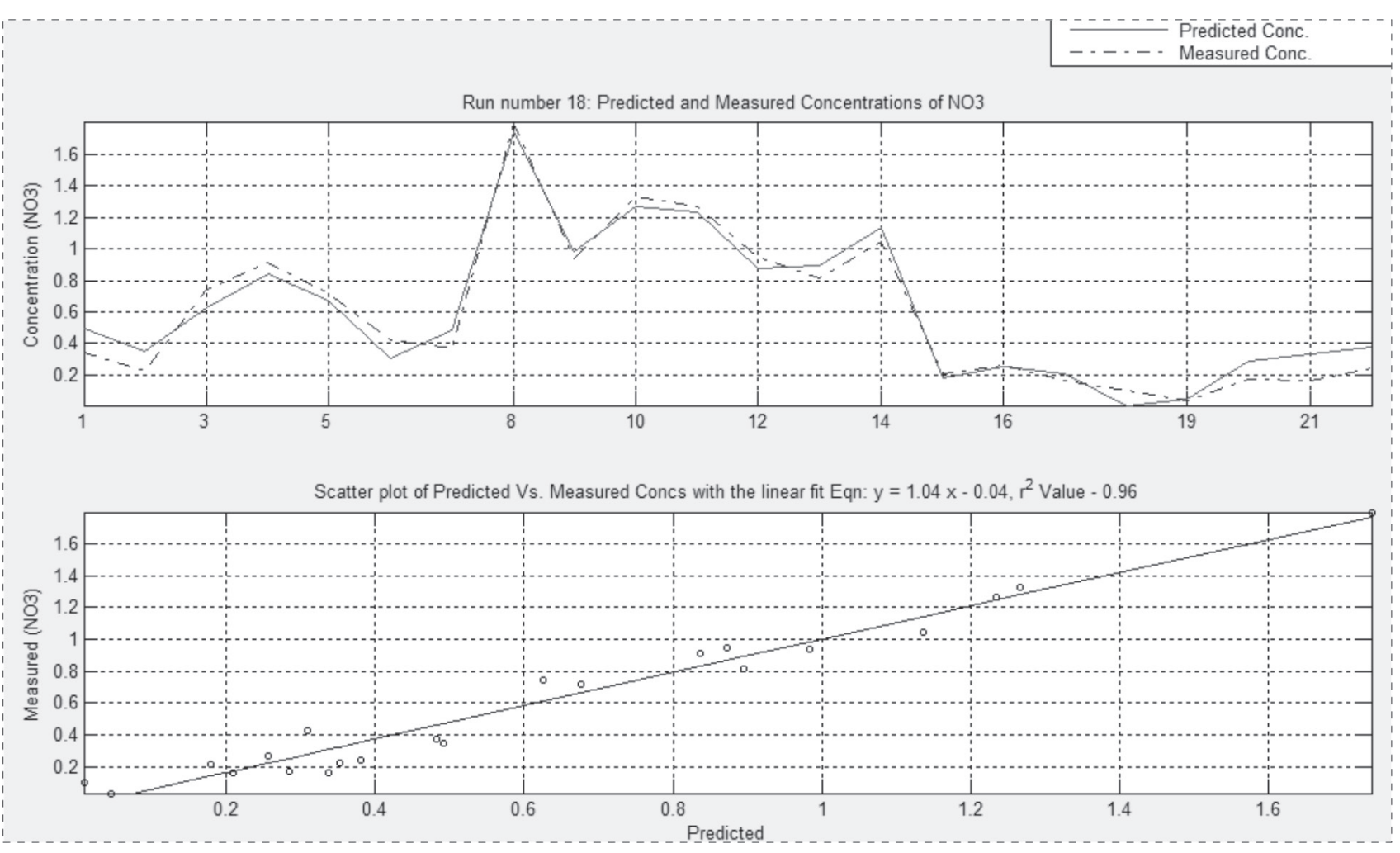

Fig. 3. Model predicted vs. measured graph and scatter plot of $\mathrm{NO}_{3}-\mathrm{N}$ for the dry season $\left(\mathrm{R}^{2}=0.96, \mathrm{e}=2.8 \%\right)$

during the dry season. The UNMIX showed that source 1 has the highest loading of $\mathrm{NO}_{2}-\mathrm{N}$ and relatively weak on others indicating the source contribution is insignificant during the dry season. On the other hand, the source 1 contribution during the wet season is significant on constituents such as $\mathrm{PO}_{4}-\mathrm{P}$, TDS, TKN and EC where the highest loading on EC could imply the prevalence of non-point source by runoff from different land uses. During the dry season, nonpoint source loading on $\mathrm{NO}_{3}-\mathrm{N}(96.83 \%)$ is very high whereas moderate loading on COD (47.1\%), EC (47.3\%) and TDS $(46.9 \%)$ could indicate the dominance of domestic waste and hence the contribution for the constituents is from domestic waste.

\section{Conclusion}

The output from this research in the study area revealed that the status of LAR is heavily polluted during both seasons. Poor waste management system coupled with uncontrolled waste release from industries, institutions, households, and other point and nonpoint sources such as agriculture and urban runoff is contributing to the river pollution. According to our finding, the most upstream section of LAR is relatively less polluted than the middle and downstream section in which LAR increases the pollution level in its course downstream. But due to the self-purification of the river at the most downstream section, the water quality level recovers to some extent but insignificantly. According to the assessment made across different monitoring stations in both dry and wet seasons on LAR, most of the physical water quality constituents are within the guideline standard whereas most of the organic and inorganic pollutants, nutrients and heavy metals have exceeded the limit. The concentration of the constituents during the dry season has shown deterioration due to reduced flow and physical aeration in the river and tributaries. FA in the area has revealed that three significant sources are responsible for LAR pollution, both during dry and wet seasons: Industrial, non-point source (agricultural and urban runoff), and domestic waste. On the other hand, the CA conducted on the LAR monitoring stations grouped the stations based on their chemical similarity. Accordingly, the rainy season produced a dendrogram with three clusters where the downstream and middle section of the main river showed similar characteristics and hence are grouped together. Stations at the most upstream and highly polluted tributaries in the middle of the catchment are grouped under clusters 2 and 3 respectively. On the other hand, the CA during the dry season classified the monitoring station into four clusters, unlike the rainy season clustering where tributaries are grouped in one.

In most cases, specifically in developing countries, it is very difficult to quantify the contribution of a certain pollution source type for an individual constituent. This is primarily due to the unavailability of continuously monitored data that in turn is due to financial constraints. Moreover, the fast-changing characteristics of the urban river water quality hinder the accurate quantification 
of pollution source contribution and composition in a river system. In LAR, however, the USEPA's UNMIX model was used to fill this gap. With the continuous and year-long monitored data, UNMIX gave a reliable and accurate result where the minimum requirement by the model was satisfied. Accordingly, $\min \mathrm{S} / \mathrm{N}$ and $\mathrm{R}^{2}$ values were predicted and measured values are found to be greater than 2 and 0.8 respectively for both seasons. The model accurately predicted the source contribution and composition of all constituents. An average error between model-predicted and measured data was $1.38 \%$ and $17.13 \%$ during dry and wet season respectively. The contribution of domestic and industrial waste for the pollution of LAR was found very high during both seasons whereas the nonpoint source contribution prevails during the wet season. Controlling point source pollution will greatly improve the water quality. Implementation of local oxygenation techniques such as the use of weir at critical locations would help improve water quality. Additionally, nonpoint source pollution reduction strategies such as growing grass strips, terracing and filtering and treatment structures at selected points would greatly help improve the pollution in LAR.

\section{Acknowledgments}

This research was financially supported by the DAAD-EECBP Home Grown PhD Scholarship Programme under (EECBP Homegrown PhD Program-2017). Arba Minch University has provided a vehicle during sample collection.

\section{Conflict of Interest}

The authors declare no conflict of interest.

\section{References}

1. SU S., ZHI J., LOU L., HUANG F., CHEN X., WU J. Spatio-temporal patterns and source apportionment of pollution in Qiantang River (China) using neural-based modeling and multivariate statistical techniques. Physics and Chemistry of the Earth, 36 (9-11), 379, 2011.

2. KAUSAR F., QADIR A., AHMAD S.R., BAQAR M. Evaluation of surface water quality on spatiotemporal gradient using multivariate statistical techniques: A case study of river Chenab, Pakistan. Polish Journal of Environmental Studies, 28 (4), 2645, 2019.

3. SINGH K.P., MALIK A., SINHA S. Water quality assessment and apportionment of pollution sources of Gomti river (India) using multivariate statistical techniques - A case study. Analytica Chimica Acta, 538 (1-2), 355, 2005.

4. YAŞAR KORKANÇ S., KAYIKÇI S., KORKANÇ M. Evaluation of spatial and temporal water quality in the Akkaya dam watershed (Niğde, Turkey) and management implications. Journal of African Earth Sciences, 129, 481, 2017.

5. CID F.D., ANTÓN R.I., PARDO R., VEGA M., CAVIEDES-VIDAL E. Modelling spatial and temporal variations in the water quality of an artificial water reservoir in the semiarid Midwest of Argentina. Analytica Chimica Acta, 705 (1-2), 243, 2011.

6. HUANG F., WANG X., LOU L., ZHOU Z., WU J. Spatial variation and source apportionment of water pollution in Qiantang River (China) using statistical techniques. Water Research, 44 (5), 1562, 2010.

7. WANG X., CAI Q., YE L., QU X. Evaluation of spatial and temporal variation in stream water quality by multivariate statistical techniques: A case study of the Xiangxi River basin, China. Quaternary International, 282, 137, 2012.

8. HAJIGHOLIZADEH M., MELESSE A.M. Assortment and spatiotemporal analysis of surface water quality using cluster and discriminant analyses. Catena, 151, 247, 2017.

9. KILONZO F., MASESE F.O., VAN GRIENSVEN A., BAUWENS W., OBANDO J., LENS P.N.L. Spatialtemporal variability in water quality and macroinvertebrate assemblages in the Upper Mara River basin, Kenya. Physics and Chemistry of the Earth, 67-69, 93, 2014.

10. BARAKAT A., EL BAGHDADI M., RAIS J., AGHEZZAF B., SLASSI M. Assessment of spatial and seasonal water quality variation of Oum Er Rbia River (Morocco) using multivariate statistical techniques. International Soil and Water Conservation Research, 4 (4), 284, 2016.

11. UNCUMUSAOĞLU A.A., AKKAN T. Assessment of water quality of yağlidere stream (Turkey) using multivariate statistical techniquess. Polish Journal of Environmental Studies, 26 (4), 1715, 2017.

12. GULGUNDI M.S., SHETTY A. Identification and Apportionment of Pollution Sources to Groundwater Quality. Environmental Processes, 3 (2), 451, 2016.

13. SUN L. Hydrochemistry of groundwater from loose layer aquifer system in northern Anhui Province, China: Source of major ions and hydrological implications. Water Practice and Technology, 10 (2), 269, 2015.

14. HUANG K., LUO X., ZHENG Z. Application of a combined approach including contamination indexes, geographic information system and multivariate statistical models in levels, distribution and sources study of metals in soils in Northern China. PLoS ONE, 13 (2), 1, 2018.

15. YOHANNES H., ELIAS E. Contamination of Rivers and Water Reservoirs in and Around Addis Ababa City and Actions to Combat It. Environment Pollution and Climate Change, 01 (02), 1, 2017.

16. ABEGAZ S.M. Investigation of input and distribution of polluting elements in Tinishu Akaki River, Ethiopia, based on the determination by ICP-MS. PhD dissertation. 2005.

17. YILMA M., KIFLIE Z., WINDSPERGER A., GESSESE N. Assessment and interpretation of river water quality in Little Akaki River using multivariate statistical techniques. International Journal of Environmental Science and Technology, 16 (7), 3707, 2019.

18. ASCHALE M., SILESHI Y., KELLY-QUINN M., HAILU D. Evaluation of potentially toxic element pollution in the benthic sediments of the water bodies of the city of Addis Ababa, Ethiopia. Journal of Environmental Chemical Engineering, 4 (4), 4173, 2016.

19. BEYENE A., ADDIS T., KIFLE D., LEGESSE W., KLOOS H., TRIEST L. Comparative study of diatoms and macroinvertebrates as indicators of severe water 
pollution: Case study of the Kebena and Akaki rivers in Addis Ababa, Ethiopia. Ecological Indicators, 9 (2), 381, 2009.

20. GHEBRETEKLE T.B. Industrial Pollution Control and Management in Ethiopia: A Case Study on Almeda Textile Factory and Sheba Leather Industry in Tigrai Regional State. PhD dissertation. The University of Warwick. 2015.

21. APHA. Standard Methods for the Examination of Water and Wastewater. American Public Health Association (Vol. 51). Washington, DC. 1999.

22. HACH. DR 2800 Spectrophotometer User Manual. Hach Company, ( $2^{\text {nd }}$ edition), 663, 2007.

23. OLSEN R.L., CHAPPEL, R.W., LOFTIS J.C. Water quality sample collection, data treatment and results presentation for principal components analysis - literature review and Illinois River watershed case study. Water Research, 46 (9), 3110, 2012.

24. WANG Y., WANG P., BAI Y., TIAN Z., LI J., SHAO X., LI B.L. Assessment of surface water quality via multivariate statistical techniques: A case study of the Songhua River Harbin region, China. Journal of HydroEnvironment Research, 7 (1), 30, 2013.

25. SINGH K.P., MALIK A., MOHAN D., SINHA S. Multivariate statistical techniques for the evaluation of spatial and temporal variations in water quality of Gomti River (India) - A case study. Water Research, 38 (18), 3980, 2004.

26. ÖZDEMIR Ö. Application of multivariate statistical methods for water quality assessment of KarasuSarmisakli creeks and Kizilirmak river in Kayseri, Turkey. Polish Journal of Environmental Studies, 25 (3), 1149, 2016.

27. OGWUELEKA T.C. Use of multivariate statistical techniques for the evaluation of temporal and spatial variations in water quality of the Kaduna River, Nigeria. Environmental Monitoring and Assessment. 2015.

28. UNCUMUSAOĞLU A., MUTLU E. Evaluating Spatial and Temporal Variation in Tuzakl1 Pond Water Using Multivariate Statistical Analysis. Polish Journal of Environmental Studies, 28 (5), 3861, 2019.

29. HAJI GHOLIZADEH M., MELESSE A.M., REDDI L. Water quality assessment and apportionment of pollution sources using APCS-MLR and PMF receptor modeling techniques in three major rivers of South Florida. Science of the Total Environment, 566-567, 1552, 2016.
30. SALIM I., SAJJAD R.U., PAULE-MERCADO M.C., MEMON S.A., LEE B.Y., SUKHBAATAR C., LEE C.H. Comparison of two receptor models PCA-MLR and PMF for source identification and apportionment of pollution carried by runoff from catchment and subwatershed areas with mixed land cover in South Korea. Science of the Total Environment, 663, 764, 2019.

31. JUAHIR H., FAHMI M., NASIR M., SAMSUDIN S., MOHAMAD I., ROSHIDE M., RAMLI N. Exploring Pathways to Sustainable Living in Malaysia: Solving the Current Environmental Issues. World Applied Sciences Journal, 14 (2002), 73, 2011.

32. SUN L. Statistical analyses of groundwater chemistry in coalmine and its hydrological implications. Journal of Applied Science and Engineering, 20 (3), 335, 2017.

33. NORRIS G., VEDANTHAM R., RACHELLE DUVALL, HENRY R.C. EPA Unmix 6.0 Fundamentals \& User Guide. US EPA, 97. Retrieved from http://www.epa.gov/ heasd/research/unmix.html 2007.

34. EEPA. Guideline Ambient Environment Standards for Ethiopia. (No. US/ETH/99/068/ETHIOPIA). Addis Ababa. 2003.

35. GURJAR S.K., TARE V. Spatial-temporal assessment of water quality and assimilative capacity of river Ramganga, a tributary of Ganga using multivariate analysis and QUEL2K. Journal of Cleaner Production, 222, 550, 2019.

36. WHO. Guidelines for drinking-water quality - $4^{\circ} \mathrm{ed}$. Geneva. WHO (fourth edi.). Geneva. 2011.

37. NAJAFPOUR S., ALKARKHI A.F.M., KADIR M.O.A., NAJAFPOUR, G.D. Evaluation of Spatial and Temporal Variation in River Water Quality. Int. J. Environ. Res., 2 (4) (September), 349, 2008.

38. PARINET B., LHOTE A., LEGUBE B. Principal component analysis: an appropriate tool for water quality evaluation and management - application to a tropical lake system. Ecological Modelling, 178, 2004.

39. MARCELLO BENEDINI. Danube River Water Data Modelling by Multivariate Data Analysis. Mikrochemical Acta, 248, 2001.

40. LING T., SOO C., LIEW J., NYANTI L., SIM S., GRINANG J. Application of Multivariate Statistical Analysis in Evaluation of Surface River Water Quality of a Tropical River. Journal of Chemistry, 2017. 